\title{
Hátrányos helyzetű társadalmi csoportok az információs társadalomban
}

A tanulmány a 2005 novemberi Információs Társadalom Szakmai Napokon elhangzott előadás kibővített változata. A szerzők három hátrányos helyzetú csoport - az idősek, a roma származásúak és a kistelepülésen élők - médiafogyasztását és az internethez való viszonyát vizsgálják a World Internet Project adatai alapján. Az elemzés tapasztalataiból kiindulva amellett érvelnek, hogy az egyes társadalmi csoportok felzárkóztatásához pontosan meghatározott egyedi fejlesztési programokra van szükség az IKT területén.

Kulcsszavak: World Internet Project, információs társadalom, digitális megosztottság, hátrányos helyzetü csoportok, romák, idősek, kistelepülésen élők, médiafogyasztás, internethaszálat

\section{Szerzői információ:}

Kollányi Bence

Médiaszociológus, az ELTE Társadalomtudományi Karán szerezte szakirányú képesítését. Az Információs Társadalom- és Trendkutató Központ munkájában 2004 nyarától vesz részt, 2005 szeptemberétól junior kutatóként dolgozik. Fő érdeklődési területe az információs társadalom mérhetôvé tétele, a felkészültségi rangsorok, valamint a kormányzati információs társadalom stratégiák elemzése. Az Infinit hírlevél Információs politika címú rovatának szerkesztôje.

E-mail: kollanyi.bence@ittk.hu

Székely Levente

Szociológus az ELTE Társadalomtudományi Karán szerzett oklevelet. 2005 óta dolgozik az ITTK-ban. Kutatási területei: kultúrafogyasztás, médiafogyasztás, új média, ifjúságügy, az információs társadalom fejlettségi szintjének mutatói, kvantitatív módszerek, statisztika. Érdeklódése kiterjed továbbá a politikai pszichológia kérdéseire és a 20. századi diktatúrákra. 2006-tól az Infinit hírlevél Szines információs társadalom rovatának szerkesztôje.

E-mail: szekely.levente@ittk.hu

Így hivatkozzon erre a cikkre:

Kollányi Bence, Székely Levente. „Hátrányos helyzetủ társadalmi csoportok az információs társadalomban”. Információs Társadalom VI, 2. szám (2006): 48-67.

$=\frac{\text { https://dx.doi.org/10.22503/inftars.VI.20 }}{\text { A folyóiratban közölt müvek }}$

a Creative Commons Nevezd meg! - Ne add el! - Így add tovább! 4.0

Nemzetközi Licenc feltételeinek megfelelóen használhatók. 
Kollányi Bence-Székely Levente

\section{Hátrányos helyzetú társadalmi csoportok az információs társa dalomban}

\section{Bevezetés}

Tanulmányunk az információs társadalom szakmai napok (ITSZN) című konferencián 2005. november 28-án elhangzott előadás alapján készült. A konferencia szervezôitól arra kaptunk felkérést, hogy a World Internet Project magyarországi adatai segítségével mutassuk be a hátrányos helyzetú társadalmi csoportok helyzetét az információs társadalomban, ebból adódóan nem célunk elméleti kérdések kifejtése, hanem inkább egyfajta problémafelvetés a rendelkezésre álló empirikus adatok alapján.

Ahogy azt már sokan, sok helyen megírták, a hátrányos helyzetú társadalmi csoportok eleve hátránnyal indulnak az információs technológiák ismerete és használata terén is, vagy - másképpen fogalmazva - a meglévố társadalmi különbségekhez nagyon hasonló társadalmi mutatók szerint szervezôdik a digitális megosztottság is. A következókben három, a közvélemény által a digitális megosztottság tekintetében (is) hátrányos helyzetúként számon tartott társadalmi csoport helyzetét elemezzük az információs társadalomban.

\section{A World Internet Project}

A World Internet Project (WIP) az internet társadalmi hatásainak vizsgálatára szerveződött széles körû́ nemzetközi kutatási program, amelyet 1999-ben a Kaliforniai Egyetem Los Angeles-i campusának (UCLA) Kommunikációpolitikai Központja (Center of Communications Policy) és a szingapúri NTU Kommunikációs Kara (School of Communications Studies) kezdeményezett. Az internethasználat terjedése - bár eltéró mértékben a világ minden tájára jellemzô, hatásai a társadalmi élet különbözố területein (a társas kapcsolatok, a kommunikációs formák, a politikai aktivitás, a szórakozás terén és a munka világában) egyre fontosabbá válnak. A WIP jelentôsége számos szempontból egyedülálló. Először is, a szokásos internetes kutatások témakörén túlmutató attitűd-, értékés viselkedésváltozók szerepeltetésével mélyebb értelmezéseket tesz lehetôvé. Másodszor, a vizsgálat kiterjed az internetet nem használó személyekre is, feltérképezve a távolmaradás okait. Harmadszor, a vizsgálat longitudinális, azaz a tíz éven keresztül évenként végrehajtott adatfelvétel lehetôvé teszi az akár egy évtizedet átfogó kutatási tervek kidolgozását is. A kutatás emellett panel jellegü, ${ }^{1}$ vagyis tíz éven át ugyanazok a kérdezettek, s ezáltal az adatok változásai és a változások okai pontosabban dokumen-

${ }^{1}$ Magyarországon a kutatásnak csak az elsố három éve (2001-2003) volt panel jellegú, azóta a panel fenntartási költségeinek megnövekedése miatt évról évre új mintán végzik a vizsgálatokat. 
tálhatók. Végül, de nem utolsósorban a WIP nagy elónye a nemzetközi összehasonlítás lehetôsége, ugyanis jó néhány olyan közös blokk szerepel a kérdőívben (az országspecifikus kérdéseken kívül), amelyek alapján a nagyszámú részt vevő ország adatai összehasonlíthatók, és az évenkénti konferenciákon az eredmények és tapasztalatok kicserélhetók. Magyarország 2001 óta vesz részt a WIP projektben. Az adatfelvételért és a gyorselemzésért felelôs Tárki Rt.-hez a kutatásban társintézetként közremúködő BMEITTK (Információs Társadalom- és Trendkutató Központ) mellett 2002-ben csatlakoztak az ELTE Szociológiai Intézetében 2002 ősze óta múködő Információs Társadalom és Hálózat Kutató Központ (ITHAKA) kutatói is. ${ }^{2}$ A 2001 óta eltelt időszakban eddig öt adatfelvételre került sor, azonban a 2005-ös adatbázis még nem készült el, ezért az elemzés során a 2004-es adatbázist használjuk.

\section{A magyarországi információs társadalom}

A rendszerváltás utáni Magyarországon az elmúlt tizenöt évben több nagyarányú, rendszerszintú változás zajlott le: a politikai rendszer demokratizálódása, a globális kapitalista termelési rendszerre való átállás és az európai integráció. Ugyanakkor a fejlett nyugati világ is, ahová tartozni akarunk, dinamikusan változik, $s$ az európai integrációra törekvő Magyarországnak ezekhez a folyamatokhoz is alkalmazkodnia kell. Ezek közül a legfontosabb az információs társadalomba való átmenet. A 2000 márciusában megrendezett lisszaboni csúcson Európa vezetói által meghatározott legfontosabb cél az volt, hogy az Európai Unió 2010-re a világ legversenyképesebb tudásalapú társadalmává váljon. A Magyar Információs Társadalom Stratégia (MITS) kiemeli, hogy „az információs társadalomba való átmenet tartalmán és hatékonyságán múlhat minden nemzet sikere Európában, és ugyanakkor ettól függ Európa pozíciójavítása és helytállása az új típusú globális világban".

Az elmúlt évtized történetét tekintve a fejlett országokban az infokommunikációs eszközök széles körú elterjedéséról számolhatunk be, ezzel szemben hazánk egyedül a vezetékes telefonhálózat és a mobiltelefónia területén volt képes lépést tartani a fejlödéssel. Magyarország lemaradása jelentôs a háztartások számítógép- és internetellátottságának területén, amit jól jelez, hogy a száz fốre eső számítógépek számában az európai átlaghoz képest háromszoros, az USA-hoz viszonyítva pedig hatszoros a lemaradásunk. A lemaradás az eleve elốnytelen induláson kívül számos más okkal is magyarázható, ezek egyike gazdasági természetú. Magyarországon ugyanis még napjainkban is indokolatlanul magasak az otthoni internethasználat költségei. Az elmúlt évtized hozott ugyan változásokat az árak tekintetében, mind abszolút, mind reálértékben ma olcsóbb az internet, mint évekkel ezelôtt, nem beszélve a szolgáltatás minôségének, illetve az

${ }^{2}$ Fontos azonban megjegyezni, hogy a kutatás finanszírozása nem központi alapokból történik, vagyis nem az alapítók biztosítják a forrásokat, s ezért a vizsgálathoz minden esetben a csatlakozó szereplók (piackutatók, tudományos intézetek stb.) teremtik elố az anyagiakat, s így az adatok is az ô birtokukban vannak. Ennek következtében vannak olyan országok, amelyeknek az adataihoz könnyebben hozzá lehet férni (pl. USA, Svédország, Japán vagy éppen Magyarország, míg más országokban még az amerikai kutatók is csak aggregált adatokat kapnak). Ritka az olyan ország, ahol - hazánkhoz hasonlóan - a kutatásról készülô éves gyorsjelentésen túl még az adatbázist is megkaphatják az érdeklódók. 
általános gazdasági helyzetnek a javulásáról, ugyanakkor a vásárlóerô-paritás nemzetközi összehasonlításában az összkép mégis kedvezőtlen. Magyarországon 2005-ben kb. a minimálbér 15\%-áért lehetett (belépő árakon) széles sávú internetszolgáltatáshoz jutni, 1-2 éves húségakciók keretében. Már ebból is látható, hogy a nagy sávszélességú kapcsolat a lakosság többségét kitevố, kevésbé tehetôs réteg számára drága (s emellett gyakran fizikailag is elérhetetlen, mert nem épült ki a hozzá szükséges technikai háttér az adott lakóhelyen - ez elsősorban a kistelepülésekre jellemzó). A dial-up csatlakozás nem jelent alternatívát, hiszen ez ma már korszerútlen és drága megoldás, amelyhez csak a szolgáltatási és telefondíjakból összetevődô és a használattal arányoșan dráguló árakon lehet hozzájutni. A széles sávú kapcsolatok elterjedése ugyanakkor önmagában is növeli a dial-up megoldás hátrányait, hiszen az internetes tartalmak és szolgáltatások igénybevétele egyre nagyobb sávszélességet igényel, tehát a modemes internetcsatlakozás esetében jelentôsen megnő a tartalmak le- és feltöltéséhez szükséges idő, ami tovább növeli a használat költségeit. A WIP-adatok tanúsága szerint a kedvezótlen helyzethez nagymértékben hozzájárul, hogy a nemhasználók - saját bevallásuk szerint leginkább az igények, a motiváció hiánya, valamint az érdektelenség miatt nem is akarnak a felhasználók közé tartozni. Az internetet nem használók tábora, amely négyszer akkora, mint a használóké, a távolmaradás okának tekintetében ugyanakkor megosztott. A nemhasználat anyagi és kulturális-kognitív okait elkülönítve jellemzốbb a materiális okok említése, de a tisztán kulturális-kognitív okok aránya is jelentốs. A részletesebb elemzés megmutatja, hogy nem csupán a legalacsonyabb jövedelmúek említenek leginkább tisztán anyagi okokat távolmaradásuk magyarázataként, hanem ugyanígy tesznek a legmagasabb jövedelmúek is, ami az ô esetükben valószínúleg rejtett kulturális okokra vezethetó vissza (Bognár-Rét, 2005). Mindez arra utal, hogy az árak további letörése csak egy lépés a penetráció növeléséhez, de minden valószínúség szerint nem az egyetlen és még csak nem is a legfontosabb.

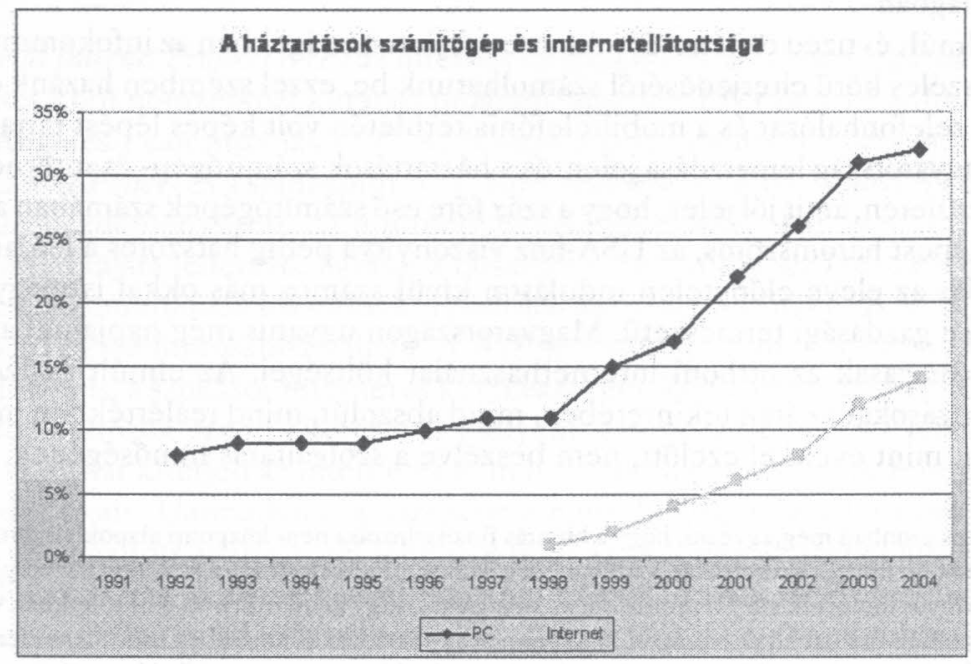

1. ábra

Forrás: Tárki-háztartásvizsgálatok, WIP =23. ÁBRA 
Az otthoni internetpenetráció bázisát a számítógéppel rendelkezô háztartások adják. Otthoni internethasználat nyilvánvalóan csak ott lehetséges, ahol van számítógép, azonban gyakoriak az internetkapcsolattal nem rendelkezô otthoni számítógépek is. Ha a háztartásokban található PC-k számát összevetjük az otthoni internet-hozzáféréssel, akkor azt láthatjuk, hogy az internetkapcsolatok számaránya az összes háztartáson belül 1998-ban 1\% körüli értéken mozgott, 1999-tól 2001-ig 2\%-ról egyenletesen emelkedett 6\%-ig, majd 2001és 2003 között a 6\%-os szintról ugrott 12\%-ra, és 2004-ben további $2 \%$-os növekedést mutatott (1. ábra).

\section{Hátrányos helyzetü társadalmi csoportok az információs társadalomban}

A Magyar Információs Társadalom Stratégia (MITS) kifejti, hogy az eEurope 2005 program egyik kiemelt prioritása az esélyegyenlóség biztosítása, a hátrányos helyzetú csoportok bevonása az információs társadalomba. Az információs társadalom keretrendszerében hátrányos helyzetúként azonosítható társadalmi csoportok más dimenziókban is hátrányos helyzetúnek bizonyulnak. Számos kutatás megerôsítette azt a felismerést, hogy „a digitális egyenlő́tlenség a hagyományos egyenlótlenségek mentén termelődik, és tovább növeli ezeket" (Bognár-Rét, 2005). Az is nyilvánvaló, hogy az ún. digitális szakadék és a társadalmi egyenlótlenség hagyományos dimenziói kölcsönösen hatnak egymásra és magyarázzák egymást (Fábián, 2005). Ebból adódóan az IKT-tudás, elsốsorban a számítógép, illetve az internet használatához szükséges ismeretek megléte közvetlenül is hatással lehet az egyén társadalmi helyzetének megváltozására. Az IKT-eszközökhöz kapcsolódó tudás, ha elônyhöz nem is juttat, hiánya mindenképpen hátrányként jelentkezik más dimenziókban, például a munkaerôpiacon. Ezenkívül létezhet közvetett hatás is: ez az elmélet arra a gondolatra épít, hogy az infokommunikációs eszközök alkalmazási készségei és az alkalmazásban való jártasság a kulturális tốke részét képezi. Az IKT-eszközök alkalmazásával egyúttal növekszik a kommunikációs potenciál, ami a társadalmi tóke növekedéséhez vezet. Mivel bizonyított tény, hogy a kulturális tóke hatással van az egyén státusára, az IKT-használati szintjének változásával az egyén eróforrásainak mennyisége is megváltozik, ami egyszersmind a társadalmi mobilitásra való esély mértékének megváltozását is jelenti. Szintén bizonyítottnak tekinthetố, hogy a társadalmi tóke erősíti a mobilitást is, a gyenge kötések ugyanis nagyban segítik a felfelé irányuló mobilitást (Rigler, 2005).

A MITS esélyegyenlőségi stratégiai fốiránya három célterületet különböztet meg: társadalmi esélyegyenlőség, területi esélyegyenlőség, interregionális esélyegyenlőség. A digitális megosztottság fớbb törésvonalai a képzett/képzetlen munkaerô, a magas/alacsony jövedelem, a fiatalok/idôsek, a nagyváros/falu, a testi-szellemi épség/fogyatékosság, valamint a férfiak/nók dichotómiái és az etnikai dimenziók mentén rajzolódnak ki. Tanulmányunkban az idôsek, a romák, valamint a kistelepülésen élók helyzetét vizsgáljuk mélyebb összefüggéseiben is az információs társadalomban. Célunk bemutatni ezeknek a hátrányos helyzetú társadalmi csoportoknak az információs társadalmon belüli helyzetét, továbbá meg kívánjuk vizsgálni, hogy milyen tényezók játszanak szerepet távolmaradásukban. 


\section{IKT-hozzáférés és -használat}

Az információs társadalom fejlettségi szintjét, amelyben elsôsorban a számítógépek, illetve az internet használata játssza a főszerepet, de fontos szerepe lehet például a mobiltelefonnak vagy különféle más hordozható technológiai eszközöknek is, a legegyszerúbb módon az infokommunikációs technológiák (IKT) eszközeihez való hozzáférést és ezek használatát tükrözố adatokból képzett aggregált mérôszámokkal közelíthetjük meg. Az infokommunikációs technológiák eszközeihez való hozzáférés az ún. hozzáférési index segítségével ragadható meg, ami több IKT-eszköz, illetve adatátviteli csatorna meglétét egyszerre vizsgálja. Az IKT hozzáférési szintjét leginkább a háztartások szociodemográfiai jellemzối (méret, korösszetétel, aktivitás), anyagi erôforrásai (jövedelem, vagyon) és a környezetüket alkotó településtípus, régió infrastrukturális adottságai határozzák meg. A használati index felépítése hasonló a hozzáférési indexéhez. Az IKT-indexek különbözóek lehetnek aszerint, hogy milyen eszközök meglétét, illetve használatát vizsgáljuk (Fábián, 2005).

Vizsgálatunkban - az információs társadalmon belüli létet szúken értelmezve egy-egy ötitemes megoldást választottunk, ${ }^{3}$ a közérthetôség kedvéért mellốztük a 0 -tól 100-ig terjedô transzformációt, ${ }^{4} \mathrm{~s}$ így a kapott változók értéke éppen annyi, amennyi eszközzel rendelkezik a háztartás, illetve amennyi eszközt használ. Az általunk felépített IKT-hozzáférési index a következố eszközökhöz való hozzáférést mutatja: vezetékes telefon, mobiltelefon, számítógép, internet, parabolaantenna. Az átlagos háztartás 2004-ben a fentiek közül 2,5 darab eszközzel rendelkezett. A vizsgált hátrányos helyzetú társadalmi csoportoknak nem egyforma a hozzáférése az említett eszközökhöz, az azonban közösen jellemzố rájuk, hogy az átlagnál kedvezốtlenebb helyzetben vannak (1. táblázat). A kistelepülések lakói állnak legközelebb az átlaghoz két eszközzel, óket szorosan követik az idősek közel két eszközzel, míg a legrosszabb helyzetben lévő roma származásúak átlagosan valamivel több mint egy eszközt birtokolnak. Hasonlattal élve: ha a használati index átlagát az addig a pontig megtett útként képzeljük el, ahol az átlagos magyar háztartás áll, akkor azt mondhatjuk, hogy ennek az útnak a $80 \%$-át már megtették a kistelepülésen élók, $70 \%$-át az idősek is, a romák azonban csak az út felénél járnak.

Az általunk létrehozott IKT-használati index az alábbi eszközök, illetve funkciók használatát tükrözi: számítógép, internet, mobiltelefon, WAP, e-mail. A megkérdezettek a fentiek közül átlagosan kevesebb mint két IKT-eszközt használnak (1. táblázat). A hozzáférésnél megfigyeltek a használatot tekintve is részben igaznak bizonyultak. A hozzáféréshez hasonlóan a használat tekintetében is elmondhatjuk, hogy az általunk vizsgált csoportok kedvezótlenebb helyzetben vannak. A hozzáférésnél alkalmazott hasonlattal élve azt mondhatjuk, hogy a kistelepülésen élók már megtették az út 70\%-át, a romák átlagosan az út felénél (50\%) járnak, az idốsek azonban alig indultak el (20\%).

${ }^{3}$ A Tárki által kifejlesztett hozzáférési indexben szerepel még a videomagnó, a használati indexben az online vásárlás.

${ }^{4} \mathrm{Az}$ IKT-indexeket 0-tól 100-ig terjedố intervallumba transzformálják, ezzel egy-egy pontszámban megadható a hozzáférés és a használat. 


\section{1. táblázat}

\begin{tabular}{|l|c|c|}
\hline Hátrányos helyzetú csoportok & Hozzáférés (db) & Használat (db) \\
\hline Roma & 1,3 & 0,9 \\
\hline Idós & 1,8 & 0,4 \\
\hline Kistelepülésen lakó & 2,0 & 1,3 \\
\hline Föátlag & 2,5 & 1,7 \\
\hline
\end{tabular}

Forrás: WIP 2004

\section{A kor hatása}

A Wim Kok-jelentés előrejelzése szerint 2050-re Európában az aktív korú (15-64 éves) népesség $18 \%$-kal csökkenni fog, a 65 év feletti korosztály viszont $60 \%$-kal bóvül. Ezek a folyamatok komoly próbakövei lehetnek az európai jóléti rendszereknek, hiszen egyre szúkebb dolgozó rétegnek kell elốteremtenie a nyugdíj és az egészségbiztosítás költségeit. Az elöregedés - ha marad a jelenlegi munkaerő-felhasználás gyakorlata - hatással lesz a potenciális gazdasági növekedésre, közel felére csökkentve azt, továbbá az ellátottak számának növekedésével növekszik az ellátásukra fordítandó összeg is. Ebból adódóan Európának már most fel kell készülnie arra, hogy az időseket az aktív munkavállalók körében tudja tartani.

Magyarország a fejlett nyugati országokhoz hasonlóan magán hordozza az öregedő társadalmak jeleit. Ez a helyzet kedvezó és kedvezốtlen folyamatok eredójeként alakul ki: javul az életminőség, növekszik a várható élettartam, ugyanakkor egyre kevesebb gyermek születik, ami a jövốben Magyarországon is munkaeróhiányhoz, illetve a fentebb vázolt problémákhoz vezethet. Hazánkban 2004-ben összesen 2,126 millió 60 éves vagy ennél idősebb ember élt, akik az összlakosság mintegy ötödrészét tették ki. Az idôsek aránya az öregedó társadalmakhoz hasonlóan Magyarországon is tovább növekszik. A 2. táblázat ennek a korosztálynak a korcsoportok szerinti belső megoszlását mutatja be.

\section{2. táblázat}

\begin{tabular}{|c|c|c|}
\hline Korcsoportok & Létszám (ezer fó) & Százalékos arány \\
\hline $60-64$ & 559 & $26 \%$ \\
\hline $65-69$ & 474 & $22 \%$ \\
\hline $70-74$ & 432 & $20 \%$ \\
\hline $75-79$ & 334 & $16 \%$ \\
\hline 80 és idôsebb & 327 & $15 \%$ \\
\hline Összesen & 2126 & $100 \%$ \\
\hline
\end{tabular}

Forrás: KSH

A digitális megosztottság egyik legfontosabb dimenziója a kor. Az IKT-hozzáférés és -használat tekintetében elmondható, hogy az idősek betagozódása az információs társadalomba még nem történt meg: bár a hozzáférés többé-kevésbé adott, ezt a lehetősé- 
get szinte egyáltalán nem használják ki. Az idősek integrálódását az információs társadalomba elősegítheti az unoka-nagyszïlő́ informatikai verseny, amelyet 2005-ben immár harmadszorra rendeztek meg. Az elért eredményt jelzi, hogy a tavalyi programot a tömeges érdeklődés mellett túljelentkezés is övezte. A verseny résztvevốivel készített felmérés ${ }^{5}$ tapasztalatai szerint az idősek - amellett, hogy egyre jobban érdeklődnek az internet iránt - leginkább az internetszolgáltatások árának csökkentésében, az oktatásban, valamint az internet népszerúsítésében látják a penetráció növekedésének kulcsát. A WIP adatai ennek némileg ellentmondanak. A 60 évnél idôsebbek ugyanis legkevésbé az árakkal indokolják az internettól való távolmaradásukat, náluk elsôsorban az érdeklődés hiánya, illetve a világháló hasznosságának leértékelése tapasztalható. $\mathrm{Az}$ internethasználatnak az idôsek körében való elterjesztésére irányuló másik fontos kezdeményezés a Budapesti Múvelődési Központ által életre hívott „Kattints rá, Nagyi” program, amely az idősebbek számára szervez számítógépes-internetes tanfolyamokat. További fontos lépést jelent, hogy a nyugdíjasok felé is bővül az eMagyarország pontok hálózata, amelyhez eddig mintegy 200 nyugdíjasklub csatlakozott.

Az internet használata számos kedvezó hatással lehet az egyén életére. A még aktív 50 év felettiek esetében, akiknek körében szintén alacsony az internetpenetráció, az információs írástudás értékes segítséget adhat a munkaerôpiacon való megmaradáshoz. Ugyanakkor fontos szerepe lehet a lelki eredetú betegségek megelózésében is. David P. Lansdale meglátása szerint az idôskorúakat leginkább a magány, az unalom, az elesettség, valamint a szellemi képességek hanyatlása veszélyezteti (Kolin, 2002). Ezeknek a gyakran egymást is erősítô tényezóknek a negatív hatását enyhítheti a szociális izoláció feloldása az internethasználat révén, ami segíthet a betegségek gyógyításában is. Jasmin McConatha és munkatársai bizonyították, hogy az internethasználat pozitívan befolyásolja a depressziós szintet (Kolin, 2002). Az internet segítségével kialakult kapcsolatok elốsegítik a családtól mint egyetlen társas közegtól való függetlenedést, az internetes informálódás naprakész tudást kínál, a külvilággal való kapcsolódási pontként jelenik meg, továbbá segíthet a generációs szakadék áthidalásában is.

\section{Társas kapcsolatok és médiafogyasztás a kor tükrében}

Megvizsgálva az egyes tevékenységekkel eltöltött idôt, a WIP-adatokból is markánsan kirajzolódik, hogy az idôsek számára mennyire fontosak a családi kapcsolatok. A család vagy barátok körében, szervezett közösségekben folytatott társas tevékenységek jelentőségét, soót a telefonkapcsolatok fontosságát is jól magyarázza a kor. ${ }^{6}$ Az idôsek esetében tulajdonképpen a család testesíti meg a társas kapcsolatokat, a fiatalabb korosztályok sokkal több idốt töltenek el barátokkal, gyakrabban járnak el klubokba, különbözó összejövetelekre, a személyes kapcsolattartás mellett a telefont is többet használják.

A különbözố médiumok elő́tt (vagy mellett) hetente eltöltött idốt is befolyásolja a kor. A hagyományos média „fogyasztása” az idősek körében sokkal népszerúbb foglalatosság, mint a fiatalok esetében. Elsốsorban a televízió jelent központi szerepet életük-

${ }^{5}$ A felmérést az Inforum program szervezôje készítette. 
ben, ezt jól jelzi az átlagosan heti 20 óránál is több idố eltöltése a televízió elốtt. A rádióhallgatás azonban - bár sokkal gyakoribb náluk, mint a tizen-huszonévesek esetében, alatta marad a középkorúak átlagos rádióhallgatási idejének, ami akár a hallás idôskori megromlásának a következménye is lehet. Az újságolvasással töltött idó a kor emelkedésével folyamatosan növekszik, a könyvolvasás a közoktatásból frissen kikerülő korcsoportok kivételével az idôsek körében a legnépszerúbb (3. ábra).

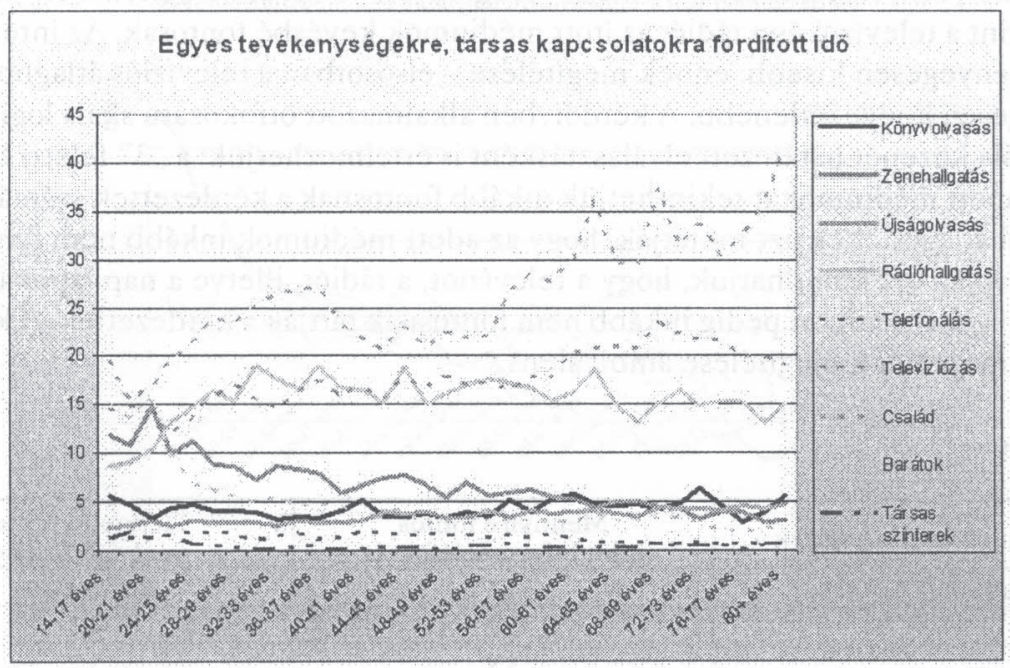

3. ábra

Forrás: WIP 2004

A következókben kísérletet teszünk arra, hogy „,a fejekbe nézve” vizsgáljuk meg az egyes médiumok, illetve a társas terek fontosságának megítélését ${ }^{7}$ az életkor függvényében. A WIP 2004-es vizsgálata a hagyományos média (televízió, rádió, napilapok, magazinok, könyvek), ${ }^{8}$ valamint a család, a barátok és a közösségi helyek mellett az internet fontosságára is rákérdezett, mint információ-, illetve mint szórakozási forrásra. Az egyes tényezóknek a szórakozás, illetve az információszerzés szempontjából való megítélése meglehetősen közel áll egymáshoz, ${ }^{9}$ ezért a „közös nevezőjüket” alkotó

${ }^{6}$ A vizsgálatot a lineáris regresszióelemzés módszerével végeztük, azzal a specifikációval, hogy a magyarázó „kor” változót kétévenként „dummyztuk”, a nominális változóból annyi kétértékű (dummy) változót hozva létre, ahány kategóriája eredetileg volt. Ez a módszer több okból is praktikus: egyrészt ebben az esetben lehetôségünk volt referenciakategóriát kialakítani (a sokszor felemlegetett „mai fiatalok” korcsoportját, a 14-17 éveseket használva fel ehhez), másrészt a módszer felszínre tudja hozni, hogy a médiafogyasztás, illetve a társas térben eltöltött idó nem feltétlenül mutat lineáris összefüggést a korral, továbbá ezzel az eljárással a regresszió normalitásigényét is sikerült csökkenteni.

${ }^{7}$ A fontosság megítélését a kérdezettek 1-tól 5-ig terjedő skálán adhatták meg (az 1-es kategória azt jelentette, hogy az adott médium „egyáltalán nem fontos”, míg az 5-ös azt, hogy „nagyon fontos”).

${ }^{8}$ Bár a könyveket nem feltétlenül szokás a hagyományos média körébe sorolni, esetünkben jó összehasonlítási alapot jelenthet.

${ }^{9}$ Médiumtípusonként a fontosság megítélése rendre 0,7-0,8-as korrelációs együtthatókkal szerepel, ami eléggé meggyốzô ahhoz, hogy aggregáltjukkal dolgozzunk tovább. 
fontosság alapján ezeket a szempontokat összevontuk. A fenti tényezôk fontosságának megítélése a következố sorrendet mutatta: család és barátok, televízió, rádió, napilapok, könyvek, magazinok, internet, helyi közösségek (3. táblázat).

Nem okoz meglepetést a család és a barátok fontosságának hangsúlyozása, hiszen fentebb láthattuk, hogy minden korcsoportban a családi körben eltöltött idő a legjelentôsebb. Ugyanakkor a helyi közösségeket, klubokat az átlag nem tartja fontosnak sem információ-, sem szórakozási forrásként. A legfontosabb médium a kérdezettek megítélése szerint a televízió és a rádió, az írott médiumok kevésbé fontosak. Az internet fontossága lényegesen kisebb, ennek megítélése - elsősorban a televíziós átlaghoz képest - lényegesen kedvezốtlenebb. A kérdóívben alkalmazott ötfokozatú skála logikája szerint a skála közepét határozott elválasztásként is értelmezhetjük: a „3” feletti átlagértékeket kapott médiumokat tekinthetjük inkább fontosnak a kérdezettek számára, míg a „3” alatti átlagértékek azt mutatják, hogy az adott médiumok inkább nem fontosak. E logika alapján azt mondhatjuk, hogy a televíziót, a rádiót, illetve a napilapokat inkább fontosnak, az internetet pedig inkább nem fontosnak tartják a kérdezettek. A könyvek, illetve a magazinok megítélése ambivalens.

3. táblázat

\begin{tabular}{|l|c|c|}
\hline \multicolumn{1}{|c|}{ Médiumok, közösségek } & $\begin{array}{c}\text { Mennyire fontos } \\
\text { mint információforrás }\end{array}$ & $\begin{array}{c}\text { Mennyire fontos } \\
\text { mint szórakozás }\end{array}$ \\
\hline Család, barátok & 4,3 & 4,4 \\
\hline Televízió & 4,2 & 4,1 \\
\hline Rádió & 3,8 & 3,7 \\
\hline Napilapok & 3,5 & 3 \\
\hline Könyvek & 3 & 3,2 \\
\hline Magazinok & 2,8 & 2,9 \\
\hline Internet & 2 & 1,8 \\
\hline Helyi közösségek, klubok & 1,5 & 1,6 \\
\hline
\end{tabular}

Forrás: WIP 2004

A fontosság megítélését jelző aggregált változók standardizáltak. Ez a tulajdonság az ábrázolhatóság miatt különösen elő́nyös, ha azt akarjuk bemutatni, hogy miként térnek el a mintabeli főátlagtól az egyes korcsoportok. A médiafogyasztás, illetve a társas együttlét idejénél alkalmazott lineáris regresszióhoz hasonló megoldást alkalmazva azt találtuk, hogy az egyes források fontosságának megítélése összefügg az életkorral, elsôsorban az internet fontosságát nem látják egyformán az egyes korcsoportok. A hagyományos médiumok fontosságának megítélésében megfigyelhető, hogy azok a médiumok, amelyeket a fiatalok az átlagoshoz képest fontosabbnak tekintenek, vagyis a könyvek és a magazinok az idôsek esetében az átlagoshoz képest kevésbé fontosak, és fordítva, a fiatalok által kevésbé fontosnak tartott médiumok, a televízió és a rádió az idôsek szemében fontosabbak. A család és a barátok szerepe mint információforrás, illetve mint szórakozási forrás a 60 éven felettiek esetében inkább nem fontos, míg a fiatalok azt inkább fontosnak tartják. A helyi közösségek inkább fontosak mindkét csoport számára, itt az idősek esetében bizonyára nagy szerepe lehet az egyházi közösségeknek. Az aláb- 
bi grafikonra pillantva láthatjuk, hogy az internet fontosságának megítélése egészen másként alakul a kor tükrében, megítélése az életkor függvényében sokkal szélsôségesebb, mint a hagyományos médiumoké. Egyértelmúen kirajzolódik a szinte tökéletesen lineáris kapcsolat, melynek alapján elmondható, hogy minél idôsebb valaki, annál kevésbé tartja fontosnak az internetet mint információ- és szórakozási forrást.

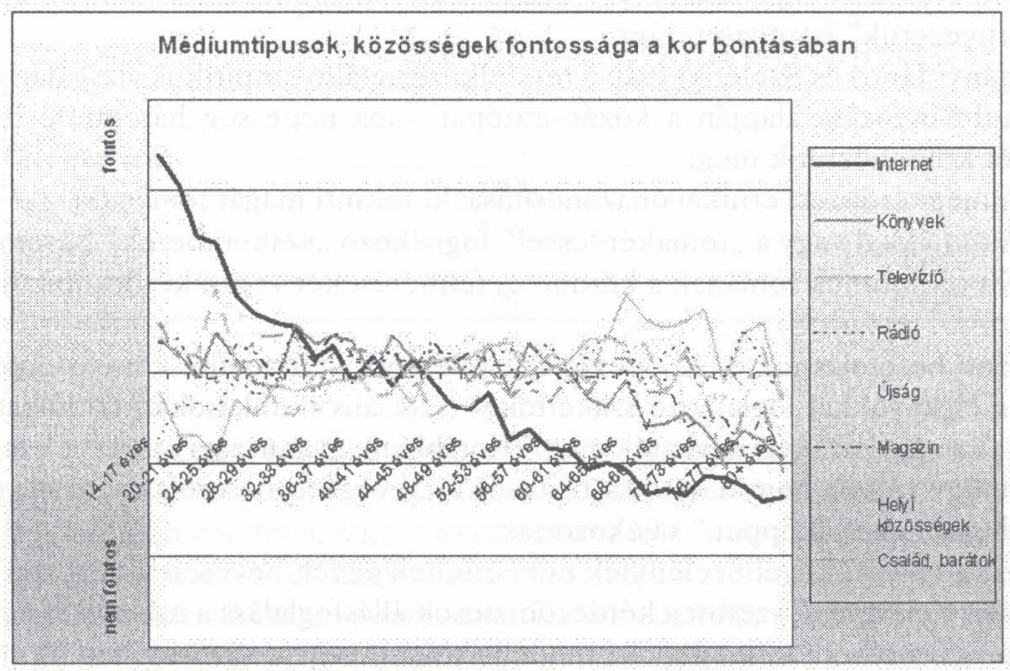

4. ábra

Forrás: WIP 2004

Az internethasználatnak az idôsekre tett jótékony hatásairól fentebb már volt szó, azonban az idôsek bekapcsolódása az információs társadalomba az egész társadalomnak is elônyére válhat, az internethasználat ugyanis csökkentheti a gondolkodásbeli generációs különbségeket, valamint új csatornát kínál a tapasztalatok átörökítésére.

\section{Roma kisebbségi médiafogyasztás}

„Minden etnikai csoport határa elmosódott: az, hogy ki van e határvonalon »belül«, s ki esik azon »kívül«, nagymértékben attól függ, hogy ki végzi az etnikai besorolást, klasszifikációt. Az etnikai besorolás távolról sem semleges, »objektív « folyamat. Az ilyenfajta besorolást mindig éles társadalmi küzdelmek határozzák meg" (LadányiSzelényi, 2001).

A roma etnikai csoport meghatározása a WIP-kérdőív készítóje számára is kihívást jelentett. Az önbesorolás helyett a kutatók a kérdezóbiztos megítélésére bízták a származás megállapítását. A fenti idézet szerzői, Ladányi János és Szelényi Iván több tanulmányukban is amellett érvelnek, hogy különösen a kérdőíves technikával felvett adatok esetében ez tekinthetố a legmegbízhatóbb eljárásnak.

A romakutatás sokáig abból a feltételezésból indult ki, hogy léteznek olyan objektív kritériumok, amelyek szerint az egyes személyeknek a roma etnikumhoz tartozása 
meghatározható: ez a felfogás nagymértékben hozzátartozik az ezen a szakterületen folytatott közép-európai kutatások hagyományaihoz. Elsóként Kemény István és munkatársai mutattak rá többek között arra is, hogy a cigányság lélekszámát illetôen a hazai népszámlálások - attól függő́en, hogy a cigány nemzetiségre vagy a cigány nyelv ismeretére kérdeztek rá - egészen eltérő eredményekre vezettek. Ezért úgy gondolták, hogy az önbesorolás elfogadása helyett azokat kell romaként azonosítani, akiket „társadalmi környezetük" is annak tekint.

Ladányi János és Szelényi Iván a rendelkezésre álló empirikus vizsgálati eredmények tanulmányozása alapján a közép-európai roma népesség háromféle besorolási rendszerét különböztetik meg:

1. A megkérdezett etnikai önazonosítása: ki tekinti magát romának?

2. A romákkal vagy a „romakérdéssel” foglalkozó „szakemberek” besorolása.

3. Kit tekintenek romának a kérdőíves felméréseket végző kérdezóbiztosok?

A fenti besorolás második kategóriáját választva, „társadalmi környezetként” Keményék a cigányokkal foglalkozó szakértóket (szociális munkásokat, tanítókat, önkormányzati tisztségviselóket) nevezték meg. ${ }^{10}$ Korábbi magyarországi kutatásaik tapasztalatai alapján úgy vélték, hogy a kérdezóbiztosok által végzett besorolás nem megbízható, a biztosok nem „kellóképpen” tájékozottak.

Ezzel a véleménnyel Szelényiék nem értenek egyet, hevesen vitába szállnak Keményékkel. Felfogásuk szerint a kérdezóbiztosok állásfoglalása a más társas helyzetekben (is) megfigyelhető ítéletalkotási modellt követi, vagyis amennyiben ók romaként tekintenek a megkérdezettekre, akkor mások is nagy valószínúséggel hasonlóan fognak viszonyulni azokhoz. Ez sajnos sok esetben azt is jelenti, hogy a romaként azonosított személy „gyanús lesz” az áruház detektívjének, „pusztán ... bórszíne, viselkedése vagy öltözködése alapján" - állítják Szelényiék. Hozzáteszik: hasonlóan hátrányos helyzetból indul a romaként besorolt személy, ha állásra jelentkezik, hiszen „a munkaadó valószínúleg az esetek jó részében szintén »megérzés « alapján dönti el, hogy a jelölt cigány-e".

Idézett tanulmányukban Ladányi és Szelényi felhívják a figyelmet arra, hogy a társadalomkutatásban komoly hagyományai vannak a megkérdezettek kérdezóbiztos becslésén alapuló etnikai besorolásának. Ezt a módszert számos népszámlálás alkalmából, többek között az Egyesült Államokban is alkalmazták. E besorolási mód mellett szóló érvként Szelényiék megjegyzik, hogy azokat a roma származású embereket, akiket a „,hétköznapi szakértóként” tevékenykedő kérdezóbiztos szúróje nem a „roma” kategóriába sorol be, valószínúleg tágabb társadalmi környezetük sem romaként azonosítja.

Az előítéletek szubjektív világán túl egyes tényezók (például az alacsony iskolai végzettség, a kulturális és más elfogadott tốkék hiánya, az eltérô életmód és az ezekból fakadó hátrányos helyzet) a statisztikákban is megjelennek. A KSH adatai szerint például a roma férfiak 60,5\%-ának nincs munkája, a fövárosban ez az arány „csak” 28,6\% (idézi Debreceni, 2004). Az alábbi táblázat a Központi Statisztikai Hivatal adatai alapján mutatja be a roma férfiak megélhetési forrásait.

${ }^{10}$ Kemény István és munkatársai 1971-ben és 1993-ban végeztek ilyen módszerrel romafelmérést Magyarországon. 
4. táblázat. A roma férfiak státusának és megélhetési forrásainak százalékos megoszlása a fốvárosban és országos viszonylatban, 2003

\begin{tabular}{|l|c|c|}
\hline \multicolumn{1}{|c|}{ Férfiak } & Budapest & Összesen \\
\hline Alkalmazott & $32,4 \%$ & $17,8 \%$ \\
\hline Vállalkozó & $15,9 \%$ & $2,9 \%$ \\
\hline Alkalmi stb. & $16,6 \%$ & $7,4 \%$ \\
\hline Tanuló & $13,1 \%$ & $11 \%$ \\
\hline Gyes stb. & - & $2,6 \%$ \\
\hline Nyugdíjas & $9,7 \%$ & $16,4 \%$ \\
\hline Munkanélküli járadék & $2,8 \%$ & $5,8 \%$ \\
\hline Más segély & $6,2 \%$ & $12,1 \%$ \\
\hline Eltartott & $6,2 \%$ & $12 \%$ \\
\hline Egyéb & - & $7,8 \%$ \\
\hline Összesen & $100 \%$ & $100 \%$ \\
\hline
\end{tabular}

Forrás: KSH

A roma népességgel kapcsolatban - mint a magyarországi szegényekkel kapcsolatban általában is - problémát jelent, hogy a vizsgált alanyok eltúnnek a hivatalos statisztikákból. Ahhoz a gondhoz, hogy a romák száma nem ismert (nem határozható meg) pontosan, még az is hozzájárul, hogy a velük kapcsolatos problémák súlyának megítéléséhez sem állnak rendelkezésre pontos adatok. Sok esetben, például a korábban gyakran a telefonkönyvekból vett mintákban a romák bekerülési esélye alacsony volt. A WIP ilyen szempontból kedvezóbb helyzetben van, hiszen a mintavétel alapjául szolgáló teljes populáció adatbázisát a Belügyminisztériumtól vásárolta meg a kutatóintézet. Ennek ellenére legalább két probléma felmerül a romákkal kapcsolatos $W I P$-adatok megbízhatóságát illetốen. Elốször is - mivel nem tudjuk a romák pontos számát a társadalomban, s ebben a tekintetben a helyi adatok sem megbízhatóak, ráadásul a kérdezóbiztosok megítélése eltér minden más statisztikai besorolástól - a roma válaszadók súlyozása lehetetlen feladat. Másodszor, nem lehet tudni, hogy a roma válaszadók milyen arányban kerültek be az eredeti mintába, illetve milyen arányban utasították el a válaszadást. A válaszmegtagadásból természetesen szisztematikus torzítások keletkezhetnek, elképzelhetô, hogy pont a leghátrányosabb helyzetben lévố romák maradnak ki a vizsgálatból. Ugyanakkor a WIP-en belül a roma válaszadók száma kellóen magas ahhoz, hogy a csoportra vonatkozóan az adatok részletes elemzése alapján megfogalmazzunk néhány állítást.

Az adatok elemzésekor itt is abból indultunk ki, hogy a modern IKT-eszközök használatának vagy az internetezési szokásoknak az elemzése önmagában nem adhat elégséges alapot egyes hátrányos helyzetû csoportoknak az információs társadalomhoz való viszonyáról.

Hisszük, hogy az „információs társadalom” fogalma nem redukálható a számítógép használóinak magas arányára vagy az internet széles körú elterjedtségére. Annak ellenére, hogy ezek a mutatók alapvetően fontos jelzőszámok, nem szabad figyelmen kívül hagyni, hogy az információk számos más forrásból is beszerezhetók. Annak ellenére, hogy nem tagadjuk az eltérő médiumok preferált használatából következő különbségeket, fontosnak tartottuk a megkérdezettek teljes információ-háztartásának áttekintését. 
A WIP változói közül ezért a médiafogyasztásra vonatkozó adatokat elemeztük elôször. A kérdőív - helyesen - rákérdez az egyes médiumok használatának fontosságára. Az alábbi grafikonon az egyes médiumok fontosságát láthatjuk a megkérdezettek életében.

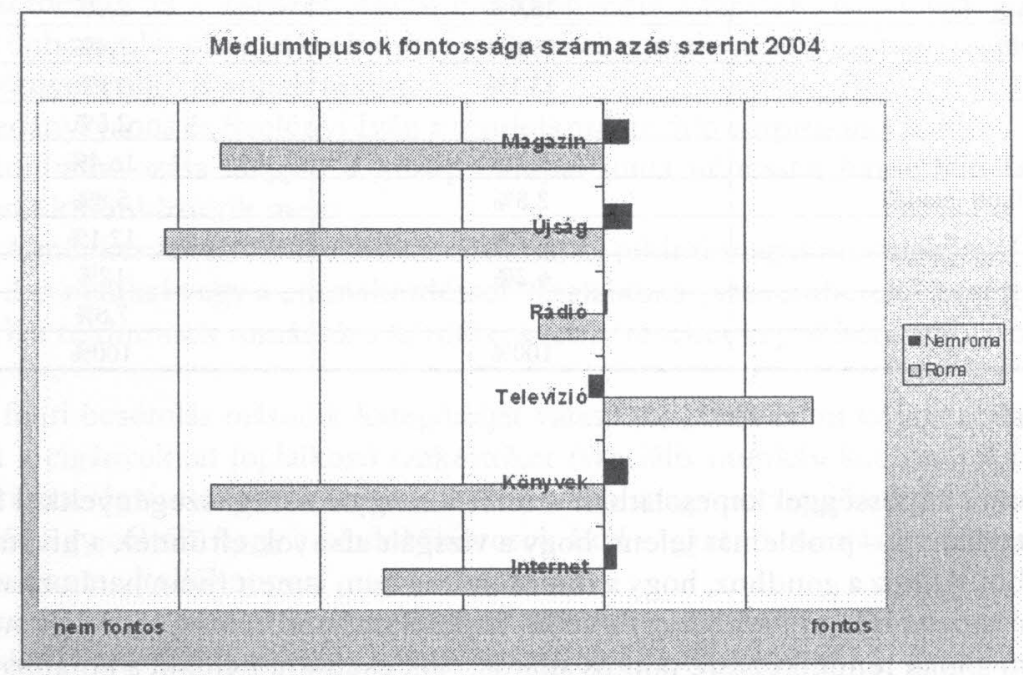

5. ábra

Forrás: WIP 2004 = 25B ÁBRA

Az ábrán jól látható, hogy az átlaghoz képest csaknem minden mutatóban lényegesen alacsonyabb a romák médiafogyasztásának szubjektív megítélése (saját maguk által). Ugyanakkor a televízió náluk szórakozási és információforrásként egyaránt lényegesen fontosabb az átlagnál. Annak ellenére, hogy a kérdéses médiumokat nem kellett sorrendbe állítani, az adatok részletes elemzéséból jól látható, hogy a fontosság megállapításakor például a televízió és a rádió súlyát egymáshoz is viszonyították.

Az adatok további elemzésének legfontosabb tanulsága az, hogy a roma csoport sokkal inkább egyetlen médiumra, a televízióra fókuszál, tehát óket „egymédiumú” csoportnak tekinthetjük. Az is jól látható, hogy a romák nem feltétlenül médiaszegény környezetben élnek, csak arról van szó, hogy a televízió erôteljes preferálása következtében információikat sokkal inkább ebból a forrásból szerzik be.

Ez egyben azt jelenti, hogy az internet növekvő fontossága mellett a roma népcsoport elérésének legmegfelelóbb eszköze - a többi médiumhoz viszonyítva - továbbra is a televízió maradt. Ez a trend 2001 és 2004 között egyáltalán nem változott.

\section{A nemhasználat lehetséges okai a romáknál}

Az elmúlt években a WIP-hez kapcsolódó hazai elemzésekben többször megjelent, hogy az internetezés elutasításának okai két nagy csoportra oszthatóak: a „nincs rá szüksége” vagy a „nem érdekli” válaszok jelentik a kognitív korlátokat. Az anyagi kor- 
látokra a „túl drága” válaszok utalnak. Általános vélemény, hogy a digitális írástudás hiánya, a „nem ért hozzá" válasz szintén a kognitív gátak közé sorolható, míg a számítógép hiánya inkább anyagi természetú kérdés.

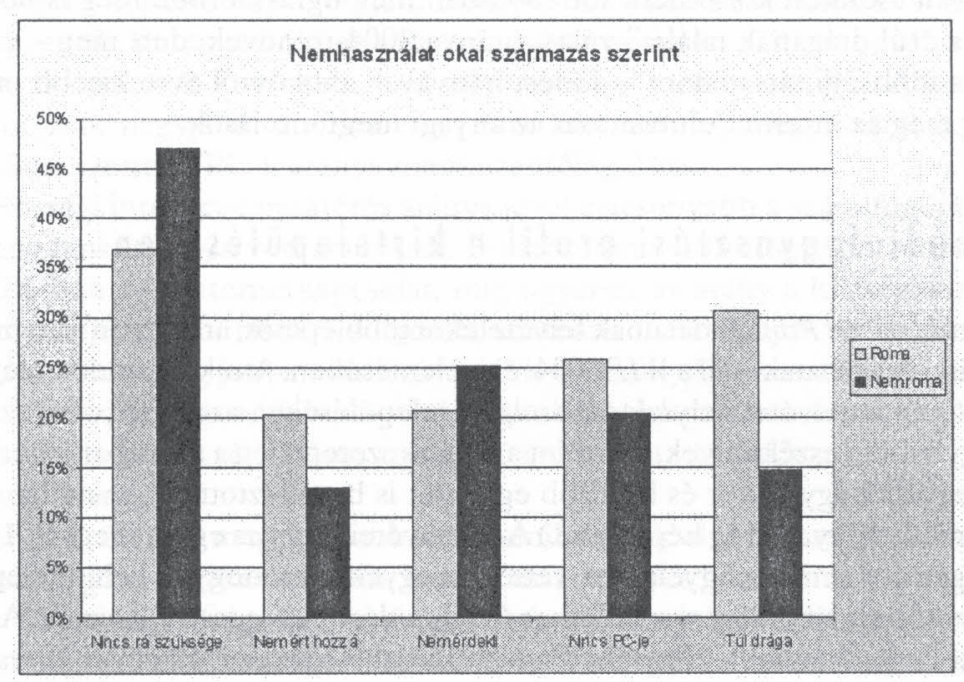

6. ábra

Forrás: WIP 2004

Ha a cigány kisebbség válaszait vizsgáljuk, a World Internet Project adatbázisában a teljes népességhez képest jelentôs eltéréseket figyelhetünk meg az előforduló válaszok eloszlásában. A roma megkérdezetteknél a kognitív korlátok rendre az átlagnál 5-10\%kal kisebb mértékben határozták meg az internet nemhasználatának okát. ${ }^{11} \mathrm{~A}$,nincs rá szüksége" választ a megkérdezettek 36,8\%-a jelölte meg az internet elutasításának okaként, szemben a nem roma válaszadók $47 \%$-os elófordulási gyakoriságával. Ehhez hasonló különbség figyelhetố meg a „nem érdekli” válaszok eloszlásával kapcsolatban itt a roma válaszadók 20,7\%-a áll szemben a többségi társadalom 25,2\%-ával.

Az alacsonyabb internethasználati mutatókat két további tényező, a számítógép, illetve az internet használatához szükséges tudás és az anyagi lehetôségek hiánya határozta meg. Míg a számítógépes „írástudás” megszerzésének nehézségeit korábban a kognitív korlátok közé sorolták, addig ebben az esetben korántsem ennyire egyszerú a képlet - különösen, ha a mai magyar oktatási rendszerben az átlagnál jóval rosszabb esélyekkel induló csoportként tekintünk a romákra. Célszerúbb a kognitív korlát helyett a kulturális gát kifejezést alkalmazni, amely a jelenséget közelebb hozza a társadalmi folyamatokhoz. Az internetet nem használó népességból minden ötödik roma jelölte meg a hozzáértés hiányát, míg a nem roma válaszadók esetében ugyanez a mutató csak $12,9 \%$ volt.

${ }^{11}$ Fontos megjegyezni, hogy a megkérdezettek több lehetőséget is választhattak az internet nem használatának okaként. Ezért csak csekély mértékben áll az a feltételezés, amely szerint a rosszabb anyagi helyzetben lévố romák esetében az anyagi korlátok erôteljes jelenléte nem engedte felszínre törni a kognitív gátakat. 
A romák internethasználattal kapcsolatos attitúdje a vizsgált négy év alatt a többségi társadalomhoz viszonyítva némileg eltérő irányba változott. A roma csoport fejlődési iránya elsősorban két válasz gyakoriságát tekintve tér el az átlagtól. A szakértelem hiánya lassabban csökken körükben, sốt 2003-ban még ugrásszerúen meg is nôtt. Ehhez hasonlóan a „túl drágának találja” válasz aránya 2004-re növekedett meg - ez teljesen ellentétes a többségi társadalom fejlődési irányával, ahol évról évre kisebb mértékben határozzák meg az internet elutasítását az anyagi megfontolások.

\section{Eltérő médiafogyasztási profil a kistelepüléseken}

A World Internet Project adatainak felvételekor többlépcsôs, arányosan rétegzett mintavételi eljárást alkalmaztak - áll a WIP 2004. évi jelentésében. Amikor minden megyéból kiválasztották az adatfelvétel helyszínéül szolgáló településeket, azt az alapvetô szabályt követték, hogy a megyeszékhelyek, valamint a fớváros szerepeljen a mintában, ezen túl pedig minden megyéból egy várost és legalább egy falut is beválasztottak a mintába. (Pest megyét két város és négy község képviselte.) A mintavétel során az egyes megyék 18 éven felüli lakosságának számát is figyelembe vették, megyékre és megyén belüli településtípusokra bontva. A mintát utólag nem, életkor és településtípus szerint súlyozták. A pontos és reprezentatív mintavételnek köszönhetốen az elkészült adatbázis alkalmas az ország egyes területei (régiói, illetve megyéi) között megfigyelhetô különbségek feltérképezésére.

Számítógépek a háztartásokban településtípusonként (\%)

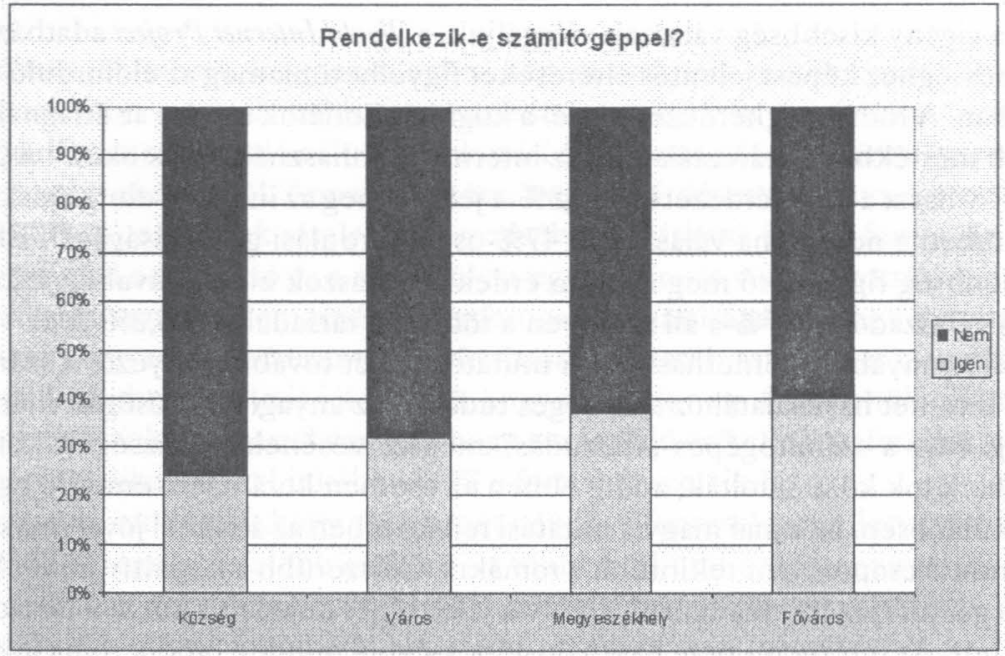

7. ábra

Forrás: WIP 2004

Magyarországon jelenleg a digitális megosztottság egyik legfontosabb meghatározó tényezôje - a hagyományos szociális hátrányokra rárakódva - a településtípus. A kistelepülések a hagyományos IKT-használati mutatók tekintetében hátrányos helyzet- 
ben vannak. A mobiltelefonnal való ellátottság például a községekben $60 \%$, míg ez az arány a többi településtípusnál eléri a $70 \%$-ot. A korábbi WIP-gyorsjelentés szerint a számítógépes ellátottság évek óta a települések urbanizáltsági szintjével arányosan növekszik. Míg a települési lejtố tetején, Budapesten a háztartások közel 40\%-ában van számítógép, addig a megyeszékhelyeken ez az arány csupán $37 \%$, az egyéb városokban pedig csak az otthonok kevesebb mint egyharmad részében van PC. A községekben ugyanakkor csak nagyjából minden negyedik háztartásra jut egy számítógép: a WIP 2004-es adatai szerint a PC-k aránya megközelítóleg $24 \%$.

A lakossági internet-hozzáférés aránya jóval alacsonyabb a számítógéppel való ellátottság országos átlagban vett arányánál. Budapesten a számítógéppel rendelkezố családok 65,9\%-ban van internetkapcsolat, míg ugyanez az arány a községekben csupán $26,3 \%$. Ha a teljes, háztartásokra súlyozott adatbázison vizsgáljuk az otthoni internethozzáférés arányát, még jobban láthatóvá válik a községek lemaradása, ebben az esetben ugyanis minden negyedik budapesti otthonból elérhető az internet $(26,4 \%)$, szemben a községekre jellemző 6,3\%-os aránnyal, ami még a városokhoz képest is kétszeres lemaradást jelent.

A helyzet ráadásul még rosszabb, mint amilyennek elsố látásra túnik. A különbségek nemcsak a penetráció arányában, hanem már az egyes hozzáférési típusok igénybevételének fizikai lehetooségeiben is megmutatkoznak: a jelenleg legnépszerúbb széles sávú technológia, a DSL országos „lefedettségében” például óriási egyenloótlenségek mutatkoznak. Az eltérố technikai környezetet jól jellemzi, hogy egy 2005-ös jelentés szerint a 2500 fő alatti lélekszámú településeken élók mindössze 3\%-ának van egyáltalán lehetôsége a DSL-szolgáltatás megvásárlására. A távközlési szolgáltató társaságoknak a fejlesztés költségeihez képest viszonylag alacsony várható kihasználtsági szint miatt a települések jelentôs hányadánál egyszerúen nem éri meg korszerúsíteni az infrastruktúrát.

Az elmúlt években történt változások még tovább rontják a kialakult képet. A fejlődés üteme az elmúlt évben valamennyi településtípus esetében csökkent. Azonban míg a települési lejtő felsóbb szintjein csupán a növekedés lassulásáról beszélhetünk, addig a korábbi években bekövetkezett lemaradás miatt eleve rosszabb helyzetból rajtoló községekben stagnálás figyelhetố meg. Ez viszont hosszú távon mindenképpen a kistelepülések leszakadását jelenti.

A megfizethetố széles sávú internet-hozzáférés hiányából következően a kistelepüléseknek sok esetben egyedi megoldásokat kell kidolgozniuk. Az öneróból megvalósított gazdaságos internet-hozzáférésre az elmúlt két évben több magyar példát is láthattunk. A helyi közösségek vezeték nélküli hálózatokat (közösségi Wi-Fi hálózatot) építettek ki Csákberényben, valamint Abán. A Cserehátban 10-15 falut érintő programot dolgoztak ki, amely az ICSSzEM és a UNDP támogatásával valósulhat meg (Molnár, 2005). A közösségi internetszolgáltatások gyakran a teleházak meglévő infrastruktúrájára épülnek rá: a kísérleti jellegúnek tekinthetố csákberényi programban ezzel a megoldással kevesebb mint 1 millió forintos költséggel építették ki a $W i-F i$ hálózatot. Az eredmények önmagukért beszélnek: a településen sikerült elérni, hogy az ott lakók havi 4000 forintért jussanak az ISDN-nél másfélszer jobb interneteléréshez. 


\section{Internet és hagyományos médiumok}

Az említett konferencián 2005. november végén elhangzott elốadásunkban azt vizsgáltuk, hogy milyen más médiahasználati különbségekre épül rá a községekben megfigyelhetó alacsony internethasználat. Azt tapasztaltuk, hogy itt a könyvolvasás, valamint a magazin- és napilapolvasás is jelentôsen eltér az átlagtól.

Mint a következő ábrán látható, a kistelepüléseken a „szubjektív médialistán” az átlagosnál fontosabbnak ítélik meg a televíziót és a rádiót. Az adatokból az is jól látszik, hogy a WIP által vizsgált négy év alatt ezek a különbségek nemhogy csökkentek volna, de gyakorlatilag folyamatosan növekedtek.

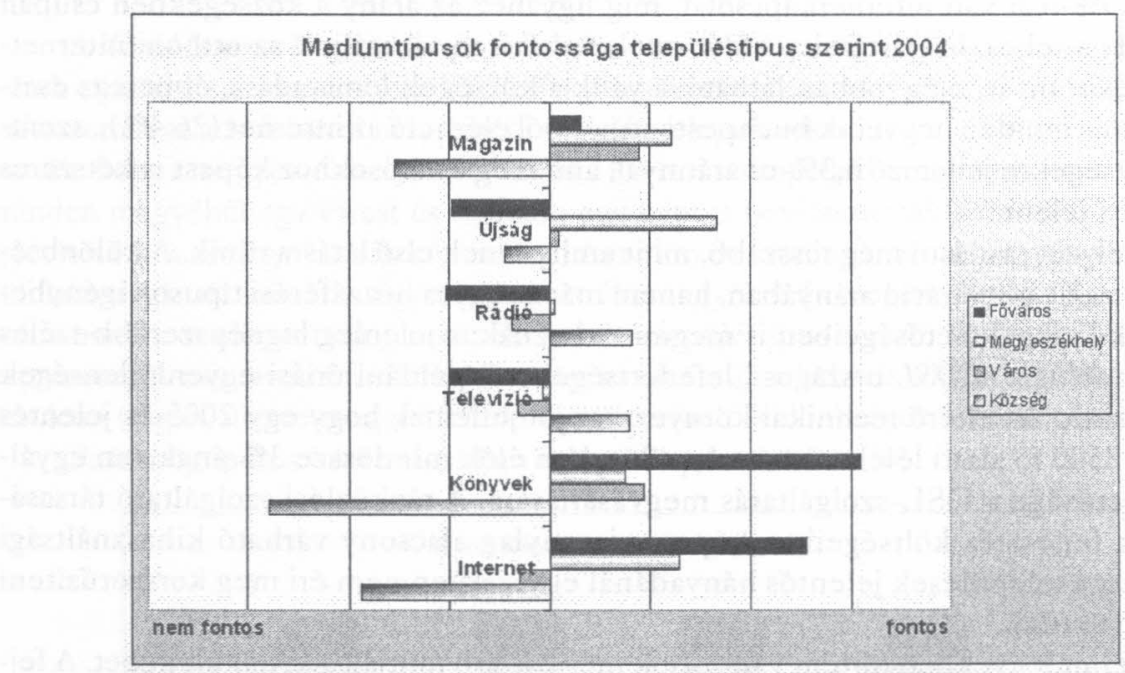

8. ábra

Forrás: WIP 2004

A WIP-kutatás egyik nagy erőssége, hogy a feltett kérdések alapján megkísérelhetjük megérteni az internet elutasításának okait. Ennek érdekében - szemben más kutatásokkal - az internetet nem használók is bekerültek a mintába. Így a kérdôiv rájuk vonatkozó részében az elmúlt öt évben rendre rákérdeztek a nemhasználat okára.

Ezek az attitűdre vonatkozó kérdések azonban - várakozásainkkal ellentétben egyáltalán nem vittek közelebb a települések közötti különbségek megértéséhez. A kistelepüléseken ugyanis a materiális okok és a kognitív tényezốk egyaránt az országos átlaghoz hasonló mértékben játszanak szerepet az internethasználatra vonatkozó döntésekben, holott azt várnánk, hogy maguknak a kistelepülések és a városok közötti szociális különbségeknek is meg kellene jelenniük a válaszokban. Ennek ellenére - mint láttuk - a községek lakóitól kapott válaszok hasonlóak a többi településtípuson élố emberektól ugyanazokra a kérdésekre kapott válaszokhoz, ez alól csak a vidéki Magyarországnál lényegesen nagyobb internetpenetrációt mutató Budapest képez kivételt. 


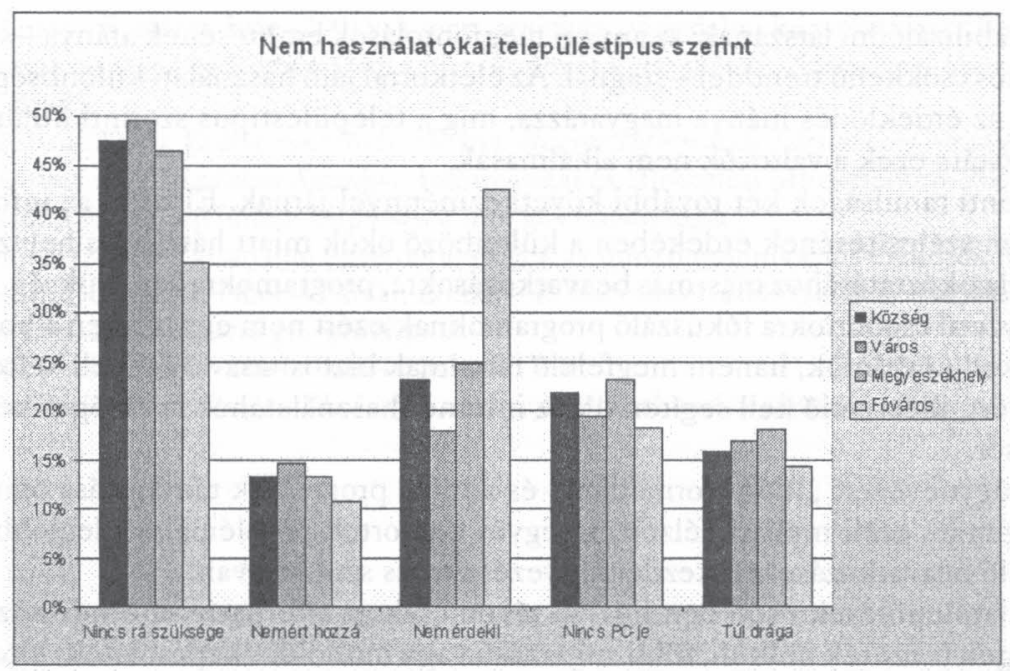

9. ábra

Forrás: WIP 2004

\section{Kitörési lehetőségek}

Magyarországon az utóbbi években lelassult az információs társadalom bővülése. Az általános trend mögött ugyanakkor heterogén mintázatot találunk, a különböző társadalmi csoportok más-más helyzetben vannak és különbözố involválódási esélyekkel rendelkeznek, amelyeket csak a részletes elemzés hozhat felszínre, ezzel segítve az IKT-hozzáférés és -használat tekintetében hátrányos helyzetú társadalmi csoportok leszakadásának megelőzését.

A WIP-adatok elemzése számos hasznos szempontot ad a hátrányos helyzetű csoportok IKT-használatának és médiafogyasztási profiljának megértéséhez. Felhívja a figyelmet arra, hogy a hátrányos helyzetú csoportok nem feltétlenül élnek médiaszegény környezetben, csupán más forrásokból szerzik be az életükhöz szükséges információkat, esetleg más médiakörnyezetben kapcsolódnak ki. A roma lakosság esetében a televízió nagyobb szerepe figyelhetố meg, a megkérdezettek szubjektív értékelése szerint más médiumok kevésbé bírnak jelentôséggel életükben. A kistelepülésen élók életében a televízió és a rádió a legfontosabb médiumok. Hasonló eredményeket kaptunk az idősek idóháztartásának elemzésekor is: a legtöbb időt ez a csoport is a rádióra és a tévére szánta.

A vizsgált három hátrányos helyzetú csoportnál a teljes lakơsság átlagánál jóval alacsonyabb internethasználati mutatókat találunk. A finomabb összefüggések megtalálásában sokat segítenek a WIP-nek azok a kérdései, amelyek az internet nemhasználatának okait firtatják. A válaszokból kiderül, hogy például a roma lakosság körében az internet nemhasználatát az átlagosnál ritkábban indokolják kognitív korlátokkal (például az érdeklődés hiányával), míg a materiális szempontok (mint a szolgáltatások ára) az átlagnál rendre magasabb arányban szerepelnek. A roma népesség körében ráadásul ezek e hát- 
rányok stabilizálódni látszanak: az anyagi megfontolások említésének aránya - szemben az általános csökkenố trenddel - stagnál. Az életkorral járó használati különbségeket elsősorban az érdeklődés hiánya magyarázza, míg a településtípus szerinti különbségek magyarázatára ezek a változók nem alkalmasak.

A fenti tanulságok két további következménnyel járnak. Először: az információs társadalom szélesítésének érdekében a különbözô okok miatt hátrányos helyzetú csoportok felzárkóztatásához más-más beavatkozásokra, programokra van szükség. A hátrányos helyzetû csoportokra fókuszáló programoknak ezért nem egyszerúen a hozzáférés esélyeit kell növelniük, hanem megfelelő tartalmak biztosításával fel kell kelteniük az érdeklődést, illetve elő kell segíteniük az internet használatához szükséges készségek fejlesztését.

Az úgynevezett „idôsinformatikai” és a roma programok támogatása önmagában nem elegendó, ezek mellett célzott, az egyes csoportok problémáira a legjobb megoldást kínáló beavatkozásokra, kezdeményezésekre is szükség van.

A kistelepülések esetében hosszú távon csak az alternatív internet-hozzáférési lehetőségek (vezeték nélküli, földi sugárzású vagy múholdas kapcsolatok) elterjedése jelenthet áttörést. Amíg ez megvalósul, addig valószínúleg a törvényi szabályozás finomításával lehetne egyenlő hozzáférési esélyeket teremteni - erre a hagyományos telefonvonalak esetében már múködő példát láthatunk.

\section{Irodalom}

Bognár Éva - Rét Zsófia (2005): A digitális egyenlőtlenségek kulturális vonatkozásai. In Dessewffy Tibor - Fábián Zoltán - Z. Karvalics László (szerk.): Internet.hu - A magyar társadalom digitális gyorsfényképe 2.

Debreceni Erzsébet (2004): A roma népesség foglalkoztatási helyzete és a roma népesség esélyegyenlóségét célzó aktivitások a fóvárosban. Fôvvárosi esélyegyenlőség módszertani füzetek sorozat, 2004.

Dessewffy Tibor (2002): Az információs társadalom lehetôségei Magyarországon. Médiakutató, 2002. tavasz. A tanulmány letölthető innen:

http://www.mediakutato.hu/cikk/2002_01_tavasz/08_informacios_tarsadalom/

Dessewffy Tibor - Galácz Anna (2002): „A dolgok új rendje”-Technológiai diffúzió és társadalmi változás. A tanulmány letölthetó innen: http://wrww.ithaka.hu/Letoltheto

Dessewffy Tibor - Galácz Anna - Gayer Zoltán (2002): Az internet és más infokommunikációs eszközök terjedése Magyarországon.

A tanulmány letölthetố innen: http://www.ithaka.hu/Letoltheto

Fábián Zoltán (2005): Az IKT-hozzáférés és -használat kölcsönhatása a társadalmi egyenlốtlenségi rendszerrel. Esettanulmány az IKT-hozzáférési és -használati indexek alkalmazásával. In Dessewffy Tibor - Fábián Zoltán -Z. Karvalics László (szerk.): Internet.hu - A magyar társadalom digitális gyorsfényképe 2.

Füzesi Péter - Pintér Róbert - Székely Levente (2005): Internetes ÁRadat: a magyar internet az árak tükrében. In Csermely Ákos (szerk.): A közszolgálatiság újrafogalmazása a digitális forradalom küszöbén - Írások az internet és a média világából. Megjelent még: Kutatási Jelentés, 2005.

Kolin Péter (2002): Idősek az információs társadalomban. EVilág, 2002. 07. http://www.pointernet.pds.hu/ujsagok/evilag/2002/07/evilag-06.html 
Ladányi János - Szelényi Iván (2001): A roma etnicitás „társadalmi konstrukciója” Bulgáriában, Magyar-országon és Romániában a piaci átmenet korszakában. Szociológiai Szemle, 2001, 4. sz., 85-95.

Molnár Szilárd (2005): Esélyegyenlőség fôirány. Magyar Információs Társadalom Stratégia, 2005.

Magyar Információs Társadalom Stratégia. Informatikai és Hírközlési Minisztérium, 2003. A teljes stratégia letölthető innen: http://www.ihm.gov.hu/strategia

Rigler András (2005): Társadalmi egyenlốtlenségek az infokommunikációs eszközök használatában. In Dessewffy Tibor - Fábián Zoltán - Z. Karvalics László (szerk.): Internet.hu - A magyar társadalom digitális gyorsfényképe 2.

„A digitális jövő térképe” 2004. Tárki-Ithaka-ITTK.

Kok, Wim: Facing the challenge - The Lisbon strategy for growth and employment. 2004. 